\title{
Bitlis Devlet Hastanesinde 2010-2016 Yılları Arasında Görülen Gıda Zehirlenmesi Vakalarının İncelenmesi
}

\author{
Seda OĞUR* \\ Bitlis Eren Üniversitesi, Mühendislik-Mimarlık Fakültesi, Gıda Mühendisliği Bölümü \\ (ORCID: 0000-0002-2041-0790)
}

\begin{abstract}
$\ddot{O} z$
Bu araştırmada Bitlis Devlet Hastanesi’nde 2010-2016 yılları arasında görülen gıda zehirlenmesi vakalarının incelenmesi amaçlanmıştır. Gerekli izinler alındıktan sonra Bitlis Devlet Hastanesi İstatistik Merkezi’ndeki yetkiliden 2010-2016 yılları arasında görülen gıda zehirlenmesi vakalarıyla ilgili istatistiksel veriler istenmiştir. $\mathrm{Bu}$ veriler arasından hastaların yaşı, cinsiyeti, işlem tarihi, teşhis, poliklinik sonucu ve işlem gördüğü ya da yatırıldığı servis bilgileri alınmıştır. Veriler SPSS $20 \circledR$ programında, sıklık ve Paerson ki-kare $\left(\chi^{2}\right)$ testleriyle değerlendirilmiş, $p<0,05$ düzeyi istatistiki açıdan anlamlı kabul edilmiştir. Bitlis Devlet Hastanesi’nde 2010-2016 yılları arasında görülen gıda zehirlenmesi vakalarının sayısının 342 olduğu tespit edilmiştir. En çok gıda zehirlenmesi vakası 18-65 yaş arasındaki bireylerde $(\% 59,1)$, erkeklerde $(\% 54,4)$ ve 2012 yılının ilk 6 ayında $(\% 51,8)$ görülmüştür. Vakaların \%47,7'sine A05.8 ICD kodlu "gıda zehirlenmeleri, diğer tanımlanmış" teşhisi konulurken; \%43,6'sına T62.8 ICD kodlu "gıda olarak yenilen diğer tanımlanmış zararlı maddelerin toksik etkisi" teşhisi konulmuştur. Hastaların \%83,9'u ayakta tedavi edilmiştir. Hastaların yaş aralığı ile poliklinik sonuçları arasındaki farkın anlamlı $(p<0,05)$ olduğu, bağışıklık sistemi yetişkinlere göre daha zayıf olan çocukların $(3-11$ yaş) daha çok $(\% 67,2)$ yatırılarak tedavi edildiği belirlenmiştir. Bitlis Devlet Hastanesi’nde görülen gıda zehirlenmesi vakalarıyla ilgili istatistiksel verilerin düzenli halleri oldukça zor elde edilmiş ve istatistiksel verilerin düzgün olarak kaydedilmediği görülmüştür.
\end{abstract}

Anahtar kelimeler: G1da zehirlenmesi, vaka, hastane, istatistiksel veri, kayıt.

\section{Examination of the Cases of Food Poisoning Seen between 2010-2016 Years in Bitlis State Hospital}

\begin{abstract}
In this research was aimed to examine the cases of food poisoning seen in Bitlis State Hospital between 2010-2016 years. After obtaining the necessary permits, statistical data about the cases of food poisoning seen between 20102016 were requested from the Bitlis State Hospital Statistics Center. From among these data, the age, sex, date of treatment, diagnosis, outcome of the outpatient clinic, and service information on which the patient was treated or hospitalized were obtained. The obtained data were evaluated in the SPSS 20® program using frequency and Pearson Chi-square $\left(\chi^{2}\right)$ tests, and $p<0,05$ level was accepted as statistically significant. It has been determined that the number of food poisoning cases in Bitlis State Hospital between 2010 and 2016 was 342. The most frequent food poisoning cases were seen in people aged 18-65 (59,1\%), in men $(54,4 \%)$ and in the first 6 months of 2012 (51,8\%). 47,7\% of the cases were diagnosed with ICD code A05.8 "food poisoning, other defined" diagnosis; $43,6 \%$ of them were diagnosed as "toxic effect of other defined harmful substances as food" with ICD code T62.8. $83,9 \%$ of the patients were treated outpatiently. It was determined the significant difference $(p<0,05)$ between the age range of the patients and outcomes of the outpatient clinic and that the children with immune system weaker than the adults $(3-11$ years) were treated more $(67,2 \%)$ by hospitalizing. Regular status of statistical data related
\end{abstract}

*Sorumlu yazar: ogursd@gmail.com

Geliş Tarihi: 25.01.2019, Kabul Tarihi: 16.07.2019 
to food poisoning cases in Bitlis State Hospital has been found to be very difficult and statistical data are not recorded properly.

Keywords: Food poisoning, case, hospital, statistical data, record.

\section{Giriș}

Bakteriler, virüsler, küfler, mayalar, bitkiler, hayvanlar, parazitler, kimyasal ve fiziksel maddelerle kontaminasyona uğramış gidaların tüketilmesi sonucu ortaya çıkan hastalıklar gıda kaynaklı hastalıklar olarak değerlendirilmektedir. Gıda kaynaklı hastalıklar kapsamında olan gıda zehirlenmesi ise herhangi bir katı ya da sıvı gıdanın tüketilmesinin ardından ortaya çıkan enfeksiyon veya intoksikasyon oluşumunun genel nitelendirmesidir $[1,2]$.

Zehirlenme halk sağlı̆̆ını tehdit eden önemli bir sorundur. Zehirlenmelerin insidansı ve nitelikleri ortaya çıktığı toplumun sosyoekonomik ve kültürel özellikleri ile değişmektedir [3].

Gıda zehirlenmeleri üç grupta incelenmektedir. Bunlar; zehirli bitki ve hayvanların neden olduğu zehirlenmeler, kimyasal gıda zehirlenmeleri, gastrointestinal sistem bozukluklarına neden olabilen gıdalarda süratle üreyebilen mikrobiyal patojenlerin neden olduğu durumlardır. Bitkilerin neden olduğu enfeksiyonlar ve zehirlenmeler; bazı gıdaların içinde doğal olarak zehirli maddeler bulunmaktadır. Zehirli mantar, solaninli patates, zehirli bal bunlara örnektir. Bu tip gidaların yanlışlıkla yenilmesi sonucunda bitkilerin neden olduğu gıda zehirlenmeleri görülür. Hayvanların neden olduğu enfeksiyonlar ve zehirlenmeler; bazı hayvanların dokularında tamamen taze de olsalar doğal olarak insanlar için zehirli olan maddeler vardır. Zehirlilikleri; görüntü, koku ve renk değişikliği gibi basit işaretlerle anlaşılamaz. Hayvanlardaki bu toksik maddeler pişirme derecelerine dirençlidir. Zehirli olan bu hayvanlar, bazı kabuklu deniz ürünleri ve bazı balıklardır. Kabuklu deniz hayvanlarından olan midye, zehirli bir plankton olan dinoflagellate ile beslendiğinde insanlar için tehlike oluşturmaktadır. Ayrıca tropikal balıkların da bir kısmı zehirlidir ve yenilmemelidir. Balık zehirlenmeleri yedi grupta toplanır. Bunlar; tetraodan, ciquatera, scombroid, clupeoid, chimaeroid, gemphylid, hallucinary mullet'dir. İçlerinde en yaygını ciquatera zehirlenmesidir. Pasifik ve Karaipler'de sık olarak rastlanır. Zehirlenmeye neden olan ısıya dirençli ciquatoksindir. Balıklar ayrıca metalleri vücutlarında biriktirerek de zehirlenmelere neden olurlar. Kimyasal gıda zehirlenmeleri; birkaç yolla olmaktadır. Bunlar inorganik maddelerin (bakır, kurşun, kalay, çinko, kadmiyum ve arsenik gibi), pestisitlerin, ilaç ve temizlik maddelerinin yanlışlıkla gıdalara bulaşması ile görülmektedir. Ayrıca, önerilen limitlerin üzerinde kullanılan gıda katkı maddeleri veya hile yaparak fazla kazanç sağlamaya çalışan kişilerin bilerek, kasıtlı olarak gıdalara ekledikleri (yağlara madensel yağlar, sütlere çamaşır sodası gibi) maddeler zehirlenmeye neden olmaktadır [4].

Gıda zehirlenmeleri her ülkede, hatta her yörede farklı özelliklere sahip olmakta, özellikle yaz dönemlerinde enfeksiyon hastalıkları polikliniklerine başvuran hastaların çoğunluğunu oluşturmakta, genellikle önem verilmemekte ve bu nedenle de yetkili mercilere bildirilmediği için asıl prevalansı hiçbir zaman öğrenilememektedir [3].

Gıda ve Tarım Örgütü (Food and Agricultural Organization- FAO), Dünya Sağlık Örgütü (World and Health Organization-WHO) ve Dünya Gıda Güvenliği Komitesi (Committee on World Food Security- CFS), kontamine olmuş gıda tüketimine bağlı olarak ortaya çıkan gıda kaynaklı hastalık ve salgınların Dünya'daki en sık görülen sağlik sorunu olduğunu bildirmektedir [2, 5].

Dünya Sağl1k Örgütü'nün 1993-1998 yılları arasında 42 ülkeyi dahil ettiği araştırma sonucuna göre; 23,538 gida zehirlenmesi olgusu kaydedilmiştir. Raporda bildirildiği üzere; Salmonella \%77 ile gida zehirlenmesine en fazla sebep olan bakteri olarak ilk sirada yer almakta, Staphylococcus aureus ise ikinci patojen olarak dikkati çekmektedir [5].

ABD Hastalıkları Kontrol ve Önleme Merkezi verilerine göre; 2010 yılında laboratuvar onaylı bir hastalığı olan 790 salgının \%42'sine Norovirüs, \%30'una Salmonella sebep olmuştur. Salgınla ilgili 29.444 hastalıktan 1.184 'ü (\%4) hastaneye yatışla sonuçlanmıştır. Salmonella salgınla ilgili en fazla (\%49) hastaneye yatışlara neden olmuştur, bunu Shiga toksin üreten E. coli (\%16) ve norovirüs (\%9) takip etmiştir. Bazı patojenlerin neden olduğu salgınlar özellikle ciddi seyretmiştir. Örneğin, Listeria salgınları hastaneye yatışa en yüksek oranda (\%82) sebep olmuş; ardından Clostridium botulinum (\%67) ve paralitik kabuklu deniz hayvanları zehirlenmesi (\%67) gelmiştir. Ölümle sonuçlanan 23 vakanın 22'si 
bakterilere (9 Listeria, 5 Salmonella, E. coli O157, 3 Clostridium perfringens ve 1 Shigella) ve biri norovirüse bağlanmıştır [6].

ABD’nin 2012 y1lına ait Gida Zehirlenmesi İstatistiklerine göre; Salmonella'nın gida zehirlenmesi olgularının \%40'ından sorumlu olduğu ortaya çıkmıştır. Campylobacter 2012 yılında 7000 kişinin hastalanmasına sebep olmuş ve bunlardan 6'sı hayatını kaybetmiştir. Daha çok kontamine deniz ürünleri sebebiyle görülen Vibrio enfeksiyonları 2012 yılında \%43 artış göstermiştir [7].

Gıda zehirlenmeleri tüm dünyada, ancak özellikle gelişmekte olan ülkelerde daha çok görülen, önemli bir halk sağlığı sorunudur. Çoğunlukla hafif seyretmesine rağmen, gıda zehirlenmesine sebep olan patojen ve konağın özellikleriyle ilgili etkenler hastalı̆̆ın bazen daha ağır seyretmesine, hatta ölümcül olmasına yol açabilmektedir [8].

Gıda kaynaklı bir salgın olarak belirtilen gida zehirlenme vakalarıyla karşılaşıldığında teşhisi konulmalı, bireysel mi kitlesel mi olduğu belirlenmeli, bir zehirlenme olgusu olduğu raporlandırılarak (Zehirlenme Vaka Bildirim Formu ile) adli makamlara ve İl Sağlı Müdürlügüne gereken bildirimler yapılmalıdır. Gerektiği durumlarda Zehir Danışma Merkezlerinden de yardım alınabilir. Zehir Danışma Merkezleri tüm zehirlenme olgularında sağlık kurumlarına tanının ve tedavinin belirlenmesinde rehberlik etmek, zehirlenmeye sebep olan etkenin saptanmasını sağlamak, etkenin değerlendirilerek zehirlenmelerin önlenmesi konularında yardımcı olmak amacıyla kurulmuştur [9].

Adli olgu grubuna giren ve davalara konu olabilen vakaların çözülebilmesi, salgın olarak görülen hastalıkların kontrol altında tutulabilmesi ve zaman kaybetmeden tedaviye başlanabilmesi için; salgının etkeni olan patojenlerin tespit edilebilmesi gerekir. Hasta ve kontrol gruplarından ve yenilen gıdalardan, kullanılan ekipmanlardan ilgili örnekler alınarak hızlı bir şekilde incelenmelidir.

Gıda zehirlenmesi belirtilerin yaşandığı hastalarda eğer Hastalıkların ve Sağlık Sorunlarının Uluslararası Sinıflama Sistemine ait ICD (International Statistical Classification of Diseases and Related Health Problems) kodlarından [10] (Tablo 1) ilgili olan kodlar teşhis olarak kaydedilmezse, aslında gida zehirlenmesi olan bir vaka farklı bir hastalık olarak kaydedilmekte ve böylece sanki gıda zehirlenmesi prevalansı azmış gibi görünmektedir.

$\mathrm{Bu}$ araştırmada Bitlis Devlet Hastanesi'nde 2010-2016 yılları arasında görülen gıda zehirlenmesi vakalarıyla ilgili istatistiksel veriler incelenerek; cinsiyet ve yaş aralığı dağılımının, ICD kodlarına göre teşhis dağılımının, poliklinik sonuçları dağılımının, tedavinin yapıldığı servis dağılımının ve 6 aylık dönemlerdeki prevalanslarının ortaya konması amaçlanmıştır. 
Tablo 1. Gıda Zehirlenmesi Teşhis Kodları (ICD-10)

\begin{tabular}{|c|c|}
\hline A05 & Bakteriyel gida zehirlenmeleri, diğer \\
\hline A05.0 & Gıda kökenli stafilokok zehirlenmesi \\
\hline A05.1 & Botulizm \\
\hline A05.2 & Gıda kökenli Clostridium perfringens [Clostridium welchii] zehirlenmesi \\
\hline A05.3 & Gıda kökenli Vibrio parahaemolyticus zehirlenmesi \\
\hline A05.4 & Gıda kökenli Bacillus cereus zehirlenmesi \\
\hline A05.8 & Gıda zehirlenmeleri, diğer tanımlanmış \\
\hline A05.9 & Bakteriyel gıda zehirlenmesi, tanımlanmamış \\
\hline T61 & Deniz ürünü olarak yenilen zararlı maddelerin zehirli etkisi \\
\hline T61.0 & "Ciguatera” balığı zehirlenmesi \\
\hline T61.1 & "Scombroid" balığı zehirlenmesi \\
\hline T61.2 & Balık ve kabuklu deniz hayvanı zehirlenmesi, diğer \\
\hline T61.8 & Deniz ürünlerinin toksik etkisi, diğer \\
\hline T61.9 & Deniz ürünlerinin tanımlanmamış toksik etkisi \\
\hline T62 & Gıda olarak yenilen diğer zararlı maddelerin toksik etkileri \\
\hline T62.0 & Mantar yemenin toksik etkisi \\
\hline T62.1 & Böğürtlen yemenin toksik etkisi \\
\hline T62.2 & Yeme diğer (bazı) bitki(ler)in toksik etkisi \\
\hline T62.8 & Gıda olarak yenilen diğer tanımlanmış zararlı maddelerin toksik etkisi \\
\hline T62.9 & Gıda olarak yenilen zararlı maddelerin toksik etkisi, tanımlanmamış \\
\hline
\end{tabular}

\section{Materyal ve Metot}

Gerekli izinler (Bitlis Eren Üniversitesi Etik Kurul Başkanlığından (Tarih: 24.06.2016, Sayı: 5468) ve Bitlis Devlet Hastanesi Başhekimliğinden) alındıktan sonra Bitlis Devlet Hastanesi İstatistik Merkezindeki yetkiliden 2010-2016 yılları arasında görülen gida zehirlenmeleri vakalarıyla ilgili istatistiksel veriler istenmiştir.

İstatistiksel veriler arasından hastaların yaşı, cinsiyeti, işlem tarihi, teşhis, poliklinik sonucu ve tedavinin yapıldığı servis bilgileri alınmıştır.

Elde edilen veriler IBM SPSS Statistics $20.0 \AA$ programında, s1klık ve Paerson ki-kare testleriyle değerlendirilmiş, $p<0,05$ düzeyi istatistiki açıdan anlamlı kabul edilmiştir.

Gıda zehirlenmesi vakası yaşayan kişilerin cinsiyeti, yaş aralığ 1 ve hastaneye başvurduğu dönem değişkenlerine göre teşhis, poliklinik sonucu ve tedavinin yapıldığı servislerin ne şekilde değiştiği tespit edilmeye çalışılmıştır.

\section{Bulgular ve Tartışma}

Bitlis Devlet Hastanesinde 2010-2016 yılları arasında görülen gıda zehirlenmesi vaka sayısının 342 olduğu ortaya çıkmış, gıda zehirlenmesi vakalarının cinsiyet, yaş aralı̆̆ı, teşhis, poliklinik sonucu ve tedavinin yapıldığı servise göre dağılımı Tablo 2'de verilmiştir. 
Tablo 2. Gıda Zehirlenmesi Vakalarının Cinsiyet, Yaş Aralığı, Teşhis, Poliklinik Sonucu ve Tedavinin Yapıldığı Servise Göre Dağılımı

\begin{tabular}{|c|c|c|c|}
\hline & & s & $\%$ \\
\hline \multirow{2}{*}{ Cinsiyet } & Kadın & 156 & 45,6 \\
\hline & Erkek & 186 & 54,4 \\
\hline \multirow{5}{*}{ Yaş aralığı } & $0-2$ & 1 & 0,3 \\
\hline & $3-11$ & 61 & 17,8 \\
\hline & $12-17$ & 73 & 21,3 \\
\hline & $18-65$ & 202 & 59,1 \\
\hline & $>65$ & 5 & 1,5 \\
\hline \multirow{6}{*}{ Teşhis } & A05.8 & 163 & 47,7 \\
\hline & T62.0 & 15 & 4,4 \\
\hline & T62.9 & 13 & 3,8 \\
\hline & T62.8 & 149 & 43,6 \\
\hline & A05.4 & 1 & 0,3 \\
\hline & A05.9 & 1 & 0,3 \\
\hline \multirow{2}{*}{ Poliklinik Sonucu } & Ayakta Tedavi & 287 & 83,9 \\
\hline & Yatırılarak Tedavi & 55 & 16,1 \\
\hline \multirow{6}{*}{ Tedavinin Yapıldığı Servis } & Acil Servis & 329 & 96,2 \\
\hline & Enfeksiyon Servisi & 1 & 0,3 \\
\hline & Çocuk Hastalıkları Servisi & 5 & 1,5 \\
\hline & İç Hastalıkları Servisi & 2 & 0,6 \\
\hline & Dermatoloji Servisi & 4 & 1,2 \\
\hline & Genel Cerrahi Servisi & 1 & 0,3 \\
\hline
\end{tabular}

Genellikle ishal, mide bulantısı ve kusma belirtisiyle ortaya çıkan gıda zehirlenmesi vakalarında semptomlar ortadan kaldırılmaya çalışılmakta, semptomların asıl sebebinin araştırılması yoluna gidilmesi bir zaman kaybı olarak görüldügü için, vakalarla ilgili raporlardan ulaşılabilen istatistiksel veriler asla gerçek vaka sayılarını yansıtmamaktadır.

Gıda zehirlenmesi yaşayan bireylerin çoğunluğunu literatürle uyumlu olarak [3, 11-14] erkeklerin $(\% 54,4)$ ve $18-65$ yaş aralı̆̆ındaki yetişkinlerin $(\% 59,1)$ oluşturduğu saptanmıştır. ICD-10 kodlarına göre hastalara konulan teşhisler incelendiğinde; ilk sırada $(\% 47,7)$ "A05.8-Gida zehirlenmeleri, diğer tanımlanmış”, ikinci sırada $(\% 43,6)$ "T62.8-Gıda olarak yenilen diğer tanımlanmış zararlı maddelerin toksik etkisi” teşhisinin yer aldığı görülmüştür. "T62.0-Mantar yemenin toksik etkisi" teşhisinin oranının ise $\% 4,4$ olduğu tespit edilmiştir. Hastaların çoğunluğunun $(\% 83,9)$ ayakta tedavi edildiği ve bu tedavinin yapıldığı birimin de genellikle $(\% 96,2)$ acil servis olduğu belirlenmiştir (Tablo 2).

Bütün ve ark. [3]'nın çalışmasında, gıda zehirlenmesi vakalarının \%28,6'sının kadın, $\% 71,4$ 'ünün erkek olduğu saptanmıştır. Yaşları bilinen 81 vakadan \%11,2'sinin 0-9 yaş gurubunda, $\%$ 41,8'inin 10-19 yaş grubunda ve \%21,4'ünün 20-29 yaş grubunda olduğu bulunmuştur. Vakaların \%51,0'inin acil servisteki tedavilerinden sonra taburcu olduğu, diğerlerinin ise acil servisteki ilk müdahalelerinden sonra, \%3,1'inin Merkezi Yoğun Bakım Ünitesi'nde, \%9,2'sinin Pediatri Kliniği'nde, \%36,7'sinin Enfeksiyon Hastalıkları Kliniği'nde yatarak tedavi gördüğü belirlenmiştir [3].

Akköse ve ark. [15]'nın yürüttüğü araştırmada, gıda ve/veya mantar zehirlenmesi sebebiyle hastaneye başvuran kişilerin \%88'inin acil servisteki tedavilerinden sonra taburcu olduğu kaydedilmiştir. 
Ülkemizde yürütülmüş araştırmalarda, acil servise başvuran zehirlenme olguları arasında ilaç zehirlenmelerinin birinci sırada, gıda zehirlenmelerinin ise ikinci sırada yer aldığ bildirilmiştir [16-21].

Gıda zehirlenmesinin sebebi olan en önemli bakteri çeșitleri; Campylobacter jejuni, Escherichia coli, Clostridium perfringens, Salmonella, Clostridium botulinum, Vibrio parahaemolyticus, Yersinia, Shigella, Staphylococcus aureus, Vibrio vulnificus, Flavobacterium, Pseudomonas, Micrococcus, Acinetobacter, Bacillus cereus, Streptecoccus, Listeria monocytogenes say1labilir [22].

Kuzey Avrupa ülkelerinde Campylobacter ve Salmonella en çok karşılaşılan patojen bakterilerdir. Ülkemizin de yer aldığı Akdeniz ülkelerinde yine Salmonella ve diğer zoonoz kaynaklı patojenler yaygın olarak görülmektedir. Türkiye' de gerçekleştirilmiş bir araştırmada güneyden kuzeye, batıdan doğuya gidildikçe gıda zehirlenmesi prevalansında bir artış olduğu belirlenmiştir [23].

Bitlis Devlet Hastanesindeki 2010-2016 y1lları arasında görülen gida zehirlenmesi vakalarının \%3'ünü oluşturduğu tespit edilen, "A5.04-G1da kökenli Bacillus cereus zehirlenmesi”nin etkeni olan $B$. cereus çoğunlukla toprak kaynaklı olduğu için sebze ve meyvelerin çoğunda bulunmakta ve genellikle sütlü pudingler, kremalar, makarna ve pirinçte hızlıca üreme yeteneğine sahip olduğu bilinmektedir [24]. Ancak, buradaki tek faktör bu bakterinin hızlıca çoğalması değil, asıl sebebi özellikle pirinç ile yapılan yemeklerin uygun olmayan şartlarda (B. cereus'un üreyeceği sıcaklık aralıklarında uzun süre bekletmek gibi) soğutulması ya da yeniden 1sıtma işlemi sırasında bakterinin inaktif olacağı sicaklığa kadar yemeğin 1sitılmamasıdır [25].

Ülkemiz'de, gida zehirlenmesine neden olan patojen bakterilerin genellikle; Listeria monocytogenes, Salmonella spp., Campylobacter spp. (termotolerant), koagülaz pozitif stafilokoklar, $E$. coli O157, Sülfit indirgeyen anaerob bakteri ve B. cereus olduğu bildirilmiştir [26]. Türk Gida Kodeksi (TGK) Mikrobiyolojik Kriterler Yönetmeliği de özellikle bu bakterilerin potansiyel tehlikesine dikkat çekerek tespit edilmelerinde kullanılan analizler üzerinde yoğunlaşmaktadır [27]. Sözkonusu patojen bakterilerin analizi T.C. Tarım ve Orman Bakanlığı laboratuvarları ile Adli Tıp Kurumunun laboratuvarlarında ve akredite olmuş özel gıda kontrol laboratuvarlarında yapılmaktadır. İstatistiki verilere göre kayıt altına alınan gıda zehirlenmesi olgularının oranının az olması gida zehirlenmeleri prevalansının Türkiye'de az olduğu düşüncesini oluşturmamalıdır. Çünkü raporlarla kaydedilen gıda zehirlenmesi olgularının oranının asıl ve aslında görünenden çok daha büyük olan rakamların oldukça az bir kısmını yansıttığı hem yetkililerce hem de toplum tarafından bilinmektedir [28].

Bitlis Devlet Hastanesindeki 2010-2016 yılları arasında görülen gıda zehirlenmesi vakalarının \%4,4'ünü "T62.0-Mantar yemenin toksik etkisi”nin teşkil ettiği görülmüştür. Zehirlenme vakalarına sebep olan mantar türü/türleri bilinmemekle birlikte; Türkiye'deki ölümle sonuçlanan mantar zehirlenmelerinin yaklaşık \%95'inden, oldukça zehirli ve Amanitaceae familyasının üyesi olan Köygöçüren mantarı (Amanita phalloides)'nın sorumlu olduğu kaydedilmiştir. Bu mantar çeşidinin yetişkin bir kişinin ölümüne sebep olması için 20-25 gram kadar yenmesinin yeterli olduğu bildirilmiştir [22]. Ölüme sebebiyet veren etken madde mantar içerisindeki "amatoksin" lerdir. Amatoksinlerin sıklıkla bilinen beş tipi arasında alfa ve beta alt grupları en önemli olanlarıdır [29, 30]. Mantar zehirlenmesi vakalarının genellikle yağmurların fazlaca yağdığı sonbahar ve ilkbahar mevsimlerinde daha çok görüldügü doğru olsa da; uygun şartlarda muhafaza edilmeyen kültür mantarlarının da toksik etkiye sahip olabileceği unutulmamalıdır [22].

Urazel ve ark. [14]'nın, gida zehirlenmesiyle ilgili 215 adli olguyu retrospektif olarak inceledikleri araștırmada olguların \%6,5'inin yoğun bakım servisinde, \%7,4'ünün çocuk hastalıkları servisinde \%29,8'inin enfeksiyon hastalıkları servisinde tedavi edildiği, \%56,3'ünün ise acil servisteki tedavilerinin ardından taburcu oldukları belirlenmiştir.

Gıda zehirlenmesi vakalarının yaşandığı dönemlerin ne şekilde değiştiğinin irdelenmesi amacıyla oluşturulan, gıda zehirlenmesi vakalarının yaşandığı dönemlerin dağılımı Tablo 3 'te verilmiştir.

Gıda zehirlenmesi vakalarının en çok yaşandığı dönemin (\%51,8) 2012 y1lının ilk 6 aylık döneminde olduğu, ikinci sırada 2013 yılının ikinci 6 aylık döneminin $(\% 17,3)$ yer aldığı bulunmuştur. 2016 yılının ikinci 6 aylık döneminde ise; gıda zehirlenmesi vakasının yaşanmadığı görülmüştür (Tablo 3). Ancak il nüfusu 341.225, Bitlis Devlet Hastanesinin bulunduğu Merkez ilçesi nüfusu 69.222 olan bir şehirde bütün bir yıl boyunca 2 adet gıda zehirlenmesi vakasının yaşandığına inanılması çok zordur. Muhtemelen bu yılda gıda zehirlenmesi ile ilgili vakaların ICD kodları hiç kaydedilmemiş veya hatalı kaydedilmiş ya da istatistiksel veriler sisteme hiç girilmemiş olabilir. 
Tablo 3. Gıda Zehirlenmesi Vakalarının Yaşandığı Dönemlerin Dağılımı

\begin{tabular}{|l|c|c|}
\hline Dönem & s & $\%$ \\
\hline 2010 (Ilk 6 Ay) & 9 & 2,6 \\
\hline 2010 (İkinci 6 Ay) & 15 & 4,4 \\
\hline 2011 (Ilk 6 Ay) & 5 & 1,5 \\
\hline 2011 (İkinci 6 Ay) & 7 & 2,0 \\
\hline 2012 (Ilk 6 Ay) & 177 & 51,8 \\
\hline 2012 (İkinci 6 Ay) & 3 & 0,9 \\
\hline 2013 (Ilk 6 Ay) & 13 & 3,8 \\
\hline 2013 (İkinci 6 Ay) & 35 & 17,3 \\
\hline 2014 (Ilk 6 Ay) & 1 & 10,2 \\
\hline 2014 (Ikinci 6 Ay) & 9 & 0,3 \\
\hline 2015 (Ilk 6 Ay) & 7 & 2,6 \\
\hline 2015 (İkinci 6 Ay) & 2 & 2,0 \\
\hline 2016 (İk 6 Ay) & 0 & 0,6 \\
\hline 2016 (İkinci 6 Ay) & 342 & 0,0 \\
\hline Toplam & & 100 \\
\hline
\end{tabular}

Oğur [31]'un 2015 y1lının bahar aylarında, Bitlis ilindeki tüketicilerin gıda zehirlenmesi konusundaki bilinç ve bilgi düzeylerinin belirlenmesi amacıyla gerçekleştirdiği araştırmasında 405 kişinin \%42,7'sinin kendisinin veya ailesindeki herhangi bir bireyin gida zehirlenmesi yaşadığ tespit edilmiştir. Oysa Tablo 3'e göre; 2015 yılında sadece 16 gıda zehirlenmesi vakasıyla karşılaşıldığı anlaşılmaktadır.

Sağlık İstatistikleri Yıllı̆̆ 2016 [32] verileri incelendiğinde; gıda zehirlenmesi vakalarının "Bazı Enfeksiyöz ve Paraziter Hastalıklar (ICD-10 Ana Tanı Kodu: A00-B99)" ve "Yaralanma, Zehirlenme ve Dış Nedenlerin Diğer Bazı Sonuçları (ICD-10 Ana Tanı Kodu: S00-T98)" kapsamına girdiği, ancak enfeksiyon hastalıklarının vaka sayıları ve insidansı tablosunda dört hastalı̆̆ın dışında diğer enfeksiyon hastalıklarına yer verilmediği görülmektedir. Bu bilgilerle gida zehirlenmesi vakalarının Türkiye genelindeki vaka sayısının ve insidansının ne olduğunu ortaya koymak mümkün değildir. Gıda zehirlenmesi vakalarında konulan teşhislerin cinsiyete göre dağılımı Tablo 4'te verilmiştir.

Tablo 4. Gıda Zehirlenmesi Vakalarında Konulan Teşhislerin Cinsiyete Göre Dağılımı $(p<0,05)$

\begin{tabular}{|c|c|c|c|c|c|c|c|c|}
\hline & & \multicolumn{6}{|c|}{ Teşhis } \\
\hline & & & $\begin{array}{c}\mathrm{A} 05.8 \\
(\mathrm{~s}=163)\end{array}$ & $\begin{array}{l}\text { T62.0 } \\
(\mathrm{s}=15)\end{array}$ & $\begin{array}{l}\text { T62.9 } \\
(\mathrm{s}=13)\end{array}$ & $\begin{array}{c}\mathrm{T} 62.8 \\
(\mathrm{~s}=149)\end{array}$ & $\begin{array}{c}\mathrm{A} 05.4 \\
(\mathrm{~s}=1)\end{array}$ & $\begin{array}{l}\text { A05.9 } \\
(\mathrm{s}=1)\end{array}$ \\
\hline \multirow{4}{*}{ Cinsiyet } & \multirow{2}{*}{ Kadın (s=156) } & $\mathrm{s}$ & 80 & 8 & 3 & 64 & 0 & 1 \\
\hline & & $\%$ & 51,3 & 5,1 & 1,9 & 41,0 & 0 & 0,6 \\
\hline & \multirow{2}{*}{ Erkek $(s=186)$} & s & 83 & 7 & 10 & 85 & 1 & 0 \\
\hline & & $\%$ & 44,6 & 3,8 & 5,4 & 45,7 & 0,5 & 0 \\
\hline
\end{tabular}

Gıda zehirlenmesi vakalarında en çok konulan teşhisin kadınlarda (\%51,3) "A05.8-Gıda zehirlenmeleri, diğer tanımlanmış" olduğu, erkeklerde (\%45,7) ise; "T62.8-Gıda olarak yenilen diğer tanımlanmış zararlı maddelerin toksik etkisi" olduğu belirlenmiştir. "T62.0-Mantar yemenin toksik etkisi" teşhisinin konulduğu kadın ve erkek sayısının hemen hemen eşit olduğu görülmüştür. Cinsiyet ile gıda zehirlenmesi vakalarında konulan teşhisler arasındaki farkın anlamlı $(p<0,05)$ olduğu bulunmuştur (Tablo 4).

Gıda zehirlenmesi vakalarında konulan teşhislerin yaş aralığına göre dağılımı Tablo 5 'te verilmiştir. $0-2$ yaş aralığında 1 vaka ve $>65$ yaşta 5 vaka olduğu için yaş aralığına göre yapılan karşılaştırmalarda bu vakalar değerlendirme dışı bırakılmıştır. Diğer yaş aralıkları ile gıda zehirlenmesi vakalarında konulan teşhisler arasındaki farkın anlamlı $(p<0,05)$ olduğu bulunmuştur. "A05.8-Gida zehirlenmeleri, diğer tanımlanmış" ve "T62.0-Mantar yemenin toksik etkisi”" teşhisinin en çok 3-11 yaş aralığındaki çocuklara konulduğu tespit edilmiş̧tir. "T62.8-Gıda olarak yenilen diğer tanımlanmış zararlı 
maddelerin toksik etkisi" ve "T62.9-Gıda olarak yenilen zararlı maddelerin toksik etkisi, tanımlanmamış" teşhisinin ise 18-65 yaş aralığındaki yetişkinlere konulduğu saptanmıştır (Tablo 5).

Tablo 5. Gıda Zehirlenmesi Vakalarında Konulan Teşhislerin Yaş Aralığına Göre Dağılımı $(p<0,05)$

\begin{tabular}{|c|c|c|c|c|c|c|c|c|}
\hline & \multicolumn{6}{|c|}{ Teşhis } \\
\hline & & & $\begin{array}{c}\text { A05.8 } \\
(s=163)\end{array}$ & $\begin{array}{l}\text { T62.0 } \\
(\mathrm{s}=15)\end{array}$ & $\begin{array}{l}\text { T62.9 } \\
(\mathrm{s}=13)\end{array}$ & $\begin{array}{c}\text { T62.8 } \\
(\mathrm{s}=149)\end{array}$ & $\begin{array}{l}\text { A05.4 } \\
(\mathrm{s}=1)\end{array}$ & $\begin{array}{l}\text { A05.9 } \\
(\mathrm{s}=1)\end{array}$ \\
\hline \multirow{6}{*}{ Yaş Aralığı } & \multirow{2}{*}{$\begin{array}{l}3-11 \\
(s=61)\end{array}$} & s & 57 & 3 & 0 & 0 & 0 & 1 \\
\hline & & $\%$ & 93,4 & 4,9 & 0,0 & 0,0 & 0,0 & 1,6 \\
\hline & \multirow{2}{*}{$\begin{array}{l}12-17 \\
(s=73) \\
\end{array}$} & S & 27 & 1 & 3 & 3 & 0 & 0 \\
\hline & & $\%$ & 37,0 & 1,4 & 4,1 & 4,1 & 0,0 & 0,0 \\
\hline & \multirow{2}{*}{$\begin{array}{l}18-65 \\
(s=202)\end{array}$} & $\mathrm{s}$ & 76 & 8 & 10 & 10 & 1 & 0 \\
\hline & & $\%$ & 37,6 & 4,0 & 5,0 & 5,0 & 0,5 & 0,0 \\
\hline
\end{tabular}
verilmiştir.

Gıda zehirlenmesi vakalarında poliklinik sonucunun cinsiyete göre dağılımı Tablo 6'da

Tablo 6. Gıda Zehirlenmesi Vakalarında Poliklinik Sonucunun Cinsiyete Göre Dağılımı $(p>0,05)$

\begin{tabular}{|c|c|c|c|c|}
\hline & \multicolumn{2}{|c|}{ Poliklinik Sonucu } \\
\hline & & & $\begin{array}{l}\text { Ayakta Tedavi Edildi } \\
\qquad(\mathrm{s}=287)\end{array}$ & $\begin{array}{l}\text { Yatırılarak Tedavi Edildi } \\
\qquad(\mathrm{s}=55)\end{array}$ \\
\hline \multirow{4}{*}{ Cinsiyet } & \multirow{2}{*}{ Kadın $(s=156)$} & s & 126 & 30 \\
\hline & & $\%$ & 80,8 & 19,2 \\
\hline & \multirow{2}{*}{ Erkek $(s=186)$} & s & 161 & 25 \\
\hline & & $\%$ & 86,6 & 13,4 \\
\hline
\end{tabular}

Yatırılarak tedavi edilen kadınların oranının $(\% 19,2)$ erkeklerin oranından $(\% 13,4)$ daha yüksek olduğu, ayakta tedavi edilen erkeklerin oranının $(\% 86,6)$ kadınların oranından $(\% 80,8)$ daha yüksek olduğu saptanmıştır (Tablo 6). Bu durumun erkek ve kadın metabolizmasının birçok hastalık karşısında gösterdiği tepkilerin farklı olmasında olduğu gibi, gıda zehirlenmesi olgusunda da farklı yanıt üretmelerinden kaynaklandığı düşünülmektedir. Ancak cinsiyet ile poliklinik sonucu arasındaki farkın anlamlı olmadığ $1(p>0,05)$ tespit edilmiştir.

Sağlık İstatistikleri Yıllığı 2016 [32] verilerine göre; gıda zehirlenmesi vakalarının da içerisinde yer aldığı "Bazı Enfeksiyöz ve Paraziter Hastalıklar (ICD-10 Ana Tanı Kodu: A00-B99)"1n ve "Yaralanma, Zehirlenme ve Dış Nedenlerin Diğer Bazı Sonuçları (ICD-10 Ana Tanı Kodu: S00-T98)"n hastane yatışlarının dağııııı tablosundaki 2014, 2015 ve 2016 yıllarına ait kadın hasta oranının erkek hasta oranından daha düşük olduğu bildirilmiştir. Gıda zehirlenmesi vakalarında poliklinik sonucunun yaş aralığına göre dağılımı Tablo 7'de verilmiştir.

Tablo 7. Gıda Zehirlenmesi Vakalarında Poliklinik Sonucunun Yaş Aralığına Göre Dağılımı $(p<0,05)$

\begin{tabular}{|c|c|c|c|c|}
\hline & \multicolumn{2}{|c|}{ Poliklinik Sonucu } \\
\hline & & & $\begin{array}{l}\text { Ayakta Tedavi Edildi } \\
\qquad(\mathrm{s}=287)\end{array}$ & $\begin{array}{l}\text { Yatırılarak Tedavi Edildi } \\
\qquad(\mathrm{s}=55)\end{array}$ \\
\hline \multirow{6}{*}{ Yaş Aralığı } & \multirow{2}{*}{$\begin{array}{l}3-11 \\
(s=61)\end{array}$} & s & 20 & 41 \\
\hline & & $\%$ & 32,8 & 67,2 \\
\hline & \multirow{2}{*}{$\begin{array}{l}12-17 \\
(s=73)\end{array}$} & s & 72 & 1 \\
\hline & & $\%$ & 98,6 & 1,4 \\
\hline & \multirow{2}{*}{$\begin{array}{l}18-65 \\
(s=202)\end{array}$} & s & 191 & 11 \\
\hline & & $\%$ & 94,6 & 5,4 \\
\hline
\end{tabular}

3-11 yaş aralığındaki çocuk hastaların daha çok yatırılarak tedavi edildiği $(\% 67,2)$ diğer yaş aralığındaki hastaların ise daha çok ayakta tedavi edildiği $(\% 98,6$ ve \%94,6) görülmüsstür. Ayrıca, yaş aralığ ile poliklinik sonucu arasındaki farkın anlamlı $(p<0,05)$ olduğu bulunmuştur (Tablo 7). 3-11 yaş aralığındaki çocukların bağışıklık sistemi daha zayıf olduğu ve henüz tam olarak gelişmediği için gıda 
zehirlenmesi olgusu adölesanlara ve yetişkinlere göre daha ağır seyredebilmektedir. Gıda zehirlenmesi vakalarında tedavinin yapıldığı servislerin cinsiyete göre dağılımı Tablo 8'de verilmiştir.

Tablo 8. Gıda Zehirlenmesi Vakalarında Tedavinin Yapıldığı Servislerin Cinsiyete Göre Dağılımı $(p>0,05)$

\begin{tabular}{|c|c|c|c|c|c|c|c|c|}
\hline & \multicolumn{6}{|c|}{ Servis } \\
\hline & & & $\begin{array}{c}\text { Acil } \\
\text { Servis } \\
(s=329)\end{array}$ & $\begin{array}{c}\text { Enfeksiyon } \\
\text { Servisi } \\
(s=1)\end{array}$ & $\begin{array}{c}\text { Çocuk } \\
\text { Hastalıkları } \\
\text { Servisi } \\
(\mathrm{s}=5)\end{array}$ & $\begin{array}{c}\text { İç Hastalıkları } \\
\text { Servisi } \\
(\mathrm{s}=2)\end{array}$ & $\begin{array}{l}\text { Dermatoloji } \\
\text { Servisi } \\
(s=4)\end{array}$ & $\begin{array}{c}\text { Genel Cerrahi } \\
\text { Servisi } \\
(\mathrm{s}=1)\end{array}$ \\
\hline \multirow{4}{*}{ Cinsiyet } & \multirow{2}{*}{ Kadin $(s=156)$} & $\mathrm{s}$ & 149 & 1 & 2 & 1 & 3 & 0 \\
\hline & & $\%$ & 95,5 & 0,6 & 1,3 & 0,6 & 1,9 & 0,0 \\
\hline & \multirow{2}{*}{ Erkek $(\mathrm{s}=186)$} & $\mathrm{s}$ & 180 & 0 & 3 & 1 & 1 & 1 \\
\hline & & $\%$ & 96,8 & 0,0 & 1,6 & 0,5 & 0,5 & 0,5 \\
\hline
\end{tabular}

Gıda zehirlenmesi vakalarında tedavinin yapıldığı servislerin başında yer alan acil serviste tedavi gören erkeklerin oranının $(\% 96,8)$ kadınların oranından $(\% 95,5)$ daha yüksek olduğu tespit edilmiş̧ir. Bu durum yatırılarak tedavi edilen kadınların oranının $(\% 19,2)$ erkeklerin oranından $(\% 13,4)$ daha yüksek olmasından kaynaklanmaktadır (Tablo 6). Ancak cinsiyet ile tedavinin yapıldığı servisler arasındaki farkın anlamlı olmadığ $1(p>0,05)$ saptanmıştır (Tablo 8).

Türkiye'de gida zehirlenmesi olgusuna rastlayan acil servisteki sağlık personelinin, zehirlenmenin etkeni olan patojenler ve delil özelliğine sahip biyolojik materyallerin alınması ve korunmasıyla ilgili eksik bilgi sahibi olduğu bildirilmiştir [33, 34].

Acil servis kliniklerinde görev yapan doktor ve yardımcı sağlık personeli, gıda zehirlenmesi olgusuyla karşılaştığında öncelikle tedavinin başarısı için hastaya doğru teşhis konulmasının öneminin gereği olarak; hastanın anamnezini ayrıntılı bir şekilde almalı ve vakit kaybetmeden yine tanıda gerekli olan kusmuk, kan, gaita gibi klinik örnekleri toplayarak ilgili laboratuvarlara hızlı bir şekilde ulaştırılmasını sağlamalıdır. Tedaviden önce veya tedavi sırasında adli merciler ile iletişim kurularak, muhakkak vakaya ait gida zehirlenmesi bildiriminin yapılması gerekmektedir. Acil servis kliniklerinde görev yapan doktor ve diğer sağlık çalışanları, gıda zehirlenmesi, bu zehirlenmenin sebebi olan patojenler konusunda hem teorikte hem de pratikte yeterli bilgi ve birikimi elde ederler, farklı eğitim uygulamaları ile bu bilgi ve birikimlerini daha da ileriye götürürler ise, gıda zehirlenmesi vakalarının kontrol altına alınabilmesi, tekrarının önlenebilmesi, ayrıca adli vakaların çözüme kavuşması daha da kolaylaşacaktır [26]. Gıda zehirlenmesi vakalarında tedavinin yapıldığı servislerin yaş aralığına göre dağılımı Tablo 9'da verilmiştir.

Tablo 9. Gıda Zehirlenmesi Vakalarında Tedavinin Yapıldığı Servislerin Yaş Aralığına Göre Dağılımı $(p<0,05)$

\begin{tabular}{|c|c|c|c|c|c|c|c|c|}
\hline & \multicolumn{6}{|c|}{ Servis } \\
\hline & & & $\begin{array}{l}\text { Acil } \\
\text { Servis } \\
(\mathrm{s}=329)\end{array}$ & $\begin{array}{c}\text { Enfeksiyon } \\
\text { Servisi } \\
\quad(s=1)\end{array}$ & $\begin{array}{l}\text { Çocuk Hastalıkları } \\
\text { Servisi } \\
(\mathrm{s}=5)\end{array}$ & $\begin{array}{c}\text { İç } \\
\text { Hastalıkları } \\
\text { Servisi } \\
(\mathrm{s}=2)\end{array}$ & $\begin{array}{l}\text { Dermatoloji } \\
\text { Servisi } \\
(s=4)\end{array}$ & $\begin{array}{l}\text { Genel Cerrahi } \\
\text { Servisi } \\
(s=1)\end{array}$ \\
\hline \multirow{6}{*}{ Yaş Aralığı } & \multirow{2}{*}{$\begin{array}{l}3-11 \\
(s=61)\end{array}$} & s & 58 & 0 & 3 & 0 & 0 & 0 \\
\hline & & $\%$ & 95,1 & 0,0 & 4,9 & 0,0 & 0,0 & 0,0 \\
\hline & \multirow{2}{*}{$\begin{array}{l}12-17 \\
(s=73)\end{array}$} & $\mathrm{s}$ & 71 & 0 & 2 & 0 & 0 & 0 \\
\hline & & $\%$ & 97,3 & 0,0 & 2,7 & 0,0 & 0,0 & 0,0 \\
\hline & \multirow{2}{*}{\multicolumn{2}{|c|}{$\begin{array}{l}18-65 \\
(s=202)\end{array}$}} & 196 & 1 & 0 & 1 & 4 & 0 \\
\hline & & & 97,0 & 0,5 & 0,0 & 0,5 & 2,0 & 0,0 \\
\hline
\end{tabular}

Yaş aralığı ile tedavinin yapıldığı servisler arasındaki farkın anlamlı $(p<0,05)$ olduğu, 3-11 yaş aralığındaki çocukların ve 12-17 yaş aralığındaki adölesanların bir kısmının $(\% 4,9$ ve $\% 2,7)$ çocuk hastalıkları servisinde yatırılarak tedavi edildiği anlaşılmıştır (Tablo 9).

Acil servis kliniklerine gelen gıda zehirlenmesi vakalarının genellikle gençlerin içinde bulunduğu yaş grubunda olduğu kaydedilmektedir [15]. Hall ve ark. [12]'nın araştırmasında gida zehirlenmesi olgularının \%75'inin, Weir ve ark. [13]'nın araştırmasında gıda zehirlenmesi olgularının 
\%70'inin 35 yaş altında olduğu, Özköse ve ark. [17]'nın araştırmasında ise gıda zehirlenmesi olgularının \%63.6'sının 25 yaş altında olduğu bildirilmektedir. Gıda zehirlenmesi vakalarında teşhislerin dönemlere göre dağılımı Tablo 10'da verilmiştir.

Tablo 10. Gıda Zehirlenmesi Vakalarında Teşhislerin Dönemlere Göre Dağılımı

\begin{tabular}{|c|c|c|c|c|c|c|c|c|}
\hline & \multicolumn{6}{|c|}{ Teşhis } \\
\hline & & & $\begin{array}{c}A 05.8 \\
(s=163)\end{array}$ & $\begin{array}{l}\text { T62.0 } \\
(\mathrm{s}=15)\end{array}$ & $\begin{array}{l}\text { T62.9 } \\
(\mathrm{s}=13)\end{array}$ & $\begin{array}{c}\text { T62.8 } \\
(\mathrm{s}=149)\end{array}$ & $\begin{array}{c}A 05.4 \\
(s=1)\end{array}$ & $\begin{array}{l}\text { A05.9 } \\
(s=1)\end{array}$ \\
\hline \multirow{28}{*}{ Dönem } & \multirow{2}{*}{2010 İlk 6 Ay (s=9) } & s & 9 & 0 & 0 & 0 & 0 & 0 \\
\hline & & $\%$ & 100,0 & 0,0 & 0,0 & 0,0 & 0,0 & 0,0 \\
\hline & \multirow{2}{*}{2010 İkinci 6 Ay (s=15) } & s & 6 & 1 & 8 & 0 & 0 & 0 \\
\hline & & $\%$ & 40,0 & 6,7 & 53,3 & 0,0 & 0,0 & 0,0 \\
\hline & \multirow{2}{*}{2011 İlk 6 Ay $(s=5)$} & s & 3 & 1 & 0 & 0 & 1 & 0 \\
\hline & & $\%$ & 60,0 & 20,0 & 0,0 & 0,0 & 20,0 & 0,0 \\
\hline & \multirow{2}{*}{2011 İkinci 6 Ay $(s=7)$} & s & 3 & 1 & 3 & 0 & 0 & 0 \\
\hline & & $\%$ & 42,9 & 14,3 & 42,9 & 0,0 & 0,0 & 0,0 \\
\hline & \multirow{2}{*}{2012 İlk 6 Ay (s=177) } & s & 26 & 3 & 1 & 147 & 0 & 0 \\
\hline & & $\%$ & 14,7 & 1,7 & 0,6 & 83,1 & 0,0 & 0,0 \\
\hline & \multirow{2}{*}{2012 İkinci 6 Ay $(s=3)$} & s & 2 & 0 & 0 & 1 & 0 & 0 \\
\hline & & $\%$ & 66,7 & 0,0 & 0,0 & 33,3 & 0,0 & 0,0 \\
\hline & \multirow{2}{*}{2013 İlk 6 Ay $(\mathrm{s}=13)$} & s & 11 & 1 & 1 & 0 & 0 & 0 \\
\hline & & $\%$ & 84,6 & 7,7 & 7,7 & 0,0 & 0,0 & 0,0 \\
\hline & \multirow{2}{*}{2013 İkinci 6 Ay (s=59) } & s & 59 & 0 & 0 & 0 & 0 & 0 \\
\hline & & $\%$ & 100,0 & 0,0 & 0,0 & 0,0 & 0,0 & 0,0 \\
\hline & \multirow{2}{*}{2014 İlk 6 Ay $(s=35)$} & s & 33 & 1 & 0 & 1 & 0 & 0 \\
\hline & & $\%$ & 94,3 & 2,9 & 0,0 & 2,9 & 0,0 & 0,0 \\
\hline & \multirow{2}{*}{2014 İkinci 6 Ay $(s=1)$} & $\mathrm{s}$ & 1 & 0 & 0 & 0 & 0 & 0 \\
\hline & & $\%$ & 100,0 & 0,0 & 0,0 & 0,0 & 0,0 & 0,0 \\
\hline & \multirow{2}{*}{2015 İlk 6 Ay (s=9) } & s & 4 & 5 & 0 & 0 & 0 & 0 \\
\hline & & $\%$ & 44,4 & 55,6 & 0,0 & 0,0 & 0,0 & 0,0 \\
\hline & \multirow{2}{*}{2015 İkinci 6 Ay $(s=7)$} & s & 5 & 1 & 0 & 0 & 0 & 1 \\
\hline & & $\%$ & 71,4 & 14,3 & 0,0 & 0,0 & 0,0 & 14,3 \\
\hline & \multirow{2}{*}{2016 İlk 6 Ay $(s=2)$} & s & 1 & 1 & 0 & 0 & 0 & 0 \\
\hline & & $\%$ & 50,0 & 50,0 & 0,0 & 0,0 & 0,0 & 0,0 \\
\hline & \multirow{2}{*}{2016 İkinci 6 Ay $(s=0)$} & $\mathrm{s}$ & 0 & 0 & 0 & 0 & 0 & 0 \\
\hline & & $\%$ & 0,0 & 0,0 & 0,0 & 0,0 & 0,0 & 0,0 \\
\hline
\end{tabular}

Gıda zehirlenmesi vakalarının en çok yaşandığı dönem olan 2012 yılının ilk 6 aylık döneminde, en fazla oranda $(\% 83,1)$ "T62.8-Gıda olarak yenilen diğer tanımlanmış zararlı maddelerin toksik etkisi” teşhisinin konulduğu belirlenmiștir. Gıda zehirlenmesi vakalarının en sık görüldüğü ikinci dönem olan 2013 yılının ikinci 6 aylık döneminde ise vakaların tamamına (\%100) "A05.8-Gıda zehirlenmeleri, diğer tanımlanmış" teşhisinin konulduğu tespit edilmiştir (Tablo 10). Gıda zehirlenmesi vakalarında poliklinik sonucunun dönemlere göre dağılımı Tablo 11'de verilmiştir. 
Tablo 11. Gıda Zehirlenmesi Vakalarında Poliklinik Sonucunun Dönemlere Göre Dağılımı

\begin{tabular}{|c|c|c|c|c|}
\hline & \multicolumn{2}{|c|}{ Poliklinik Sonucu } \\
\hline & & & $\begin{array}{l}\text { Ayakta Tedavi Edildi } \\
\qquad(\mathrm{s}=287)\end{array}$ & $\begin{array}{l}\text { Yatırilarak Tedavi Edildi } \\
\qquad(\mathrm{s}=55)\end{array}$ \\
\hline \multirow{28}{*}{ Dönem } & \multirow{2}{*}{2010 İlk 6 Ay (s=9) } & s & 9 & 0 \\
\hline & & $\%$ & 100,0 & 0,0 \\
\hline & \multirow{2}{*}{2010 İkinci 6 Ay (s=15) } & s & 15 & 0 \\
\hline & & $\%$ & 100,0 & 0,0 \\
\hline & \multirow{2}{*}{2011 İlk 6 Ay $(s=5)$} & $\mathrm{s}$ & 5 & 0 \\
\hline & & $\%$ & 100,0 & 0,0 \\
\hline & \multirow{2}{*}{2011 İkinci 6 Ay (s=7) } & $\mathrm{s}$ & 6 & 1 \\
\hline & & $\%$ & 85,7 & 14,3 \\
\hline & \multirow{2}{*}{2012 İlk 6 Ay (s=177) } & s & 176 & 1 \\
\hline & & $\%$ & 99,4 & 0,6 \\
\hline & \multirow{2}{*}{2012 İkinci 6 Ay (s=3) } & s & 3 & 0 \\
\hline & & $\%$ & 100,0 & 0,0 \\
\hline & \multirow{2}{*}{2013 İlk 6 Ay (s=13) } & s & 12 & 1 \\
\hline & & $\%$ & 92,3 & 7,7 \\
\hline & \multirow{2}{*}{2013 İkinci 6 Ay (s=59) } & s & 17 & 42 \\
\hline & & $\%$ & 28,8 & 71,2 \\
\hline & \multirow{2}{*}{2014 İlk 6 Ay (s=35) } & s & 35 & 0 \\
\hline & & $\%$ & 100,0 & 0,0 \\
\hline & \multirow{2}{*}{2014 İkinci 6 Ay (s=1) } & s & 1 & 0 \\
\hline & & $\%$ & 100,0 & 0,0 \\
\hline & \multirow{2}{*}{2015 İlk 6 Ay $(s=9)$} & s & 4 & 5 \\
\hline & & $\%$ & 44,4 & 55,6 \\
\hline & \multirow{2}{*}{2015 İkinci 6 Ay (s=7) } & s & 4 & 3 \\
\hline & & $\%$ & 57,1 & 42,9 \\
\hline & \multirow{2}{*}{2016 İlk 6 Ay (s=2) } & s & 0 & 2 \\
\hline & & $\overline{\%}$ & 0,0 & 100,0 \\
\hline & \multirow{2}{*}{2016 İkinci 6 Ay (s=0) } & s & 0 & 0 \\
\hline & & $\%$ & 0,0 & 0,0 \\
\hline
\end{tabular}

Gıda zehirlenmesi vakalarının en sık yaşandığı dönem olan 2012 yılının ilk 6 aylık döneminde, hastaların çoğunun $(\% 99,4)$ ayakta tedavi edildiği saptanmıştır. Gıda zehirlenmesi vakalarının en sık yaşandığı ikinci dönem olan 2013 yılının ikinci 6 aylık döneminde ise hastaların çoğunun $(\% 71,2)$ yatırılarak tedavi edildiği bulunmuştur (Tablo 11).

Sağlık İstatistikleri Y1llığ 2016 [32] verileri incelendiğinde; gıda zehirlenmesi vakalarının da içerisinde yer aldığ "Bazı Enfeksiyöz ve Paraziter Hastalıklar (ICD-10 Ana Tanı Kodu: A00-B99)"1n hastane yatışlarının dağılımının 2014 yılında \%2,9, 2015 y1lında \%2,6, 2016 yılında \%2,6, "Yaralanma, Zehirlenme ve Dış Nedenlerin Diğer Bazı Sonuçları (ICD-10 Ana Tanı Kodu: S00-T98)"n hastane yatışlarının dağılımının 2014 yılında \%4,9, 2015 yılında \%4,8, 2016 yılında \%5,0 olduğu kaydedilmiş̧ir. Ayrıca hastanelerde yatan hastaların ortalama kalış günü "Bazı Enfeksiyöz ve Paraziter Hastalıklar (ICD-10 Ana Tanı Kodu: A00-B99)"da 2013 yılında 3,5, 2014 yılında 3,5, 2015 y1lında 3,6, 2016 yılında 4,0, "Yaralanma, Zehirlenme ve Dış Nedenlerin Diğer Bazı Sonuçları (ICD-10 Ana Tanı Kodu: S00-T98)"nda 2013 yılında 4,6, 2014 yılında 5, 2015 yılında 5, 2016 yllında 5 olduğu rapor edilmiştir. Gıda zehirlenmesi vakalarında tedavinin yapıldığı servislerin dönemlere göre dağılımı Tablo 12 'de verilmiştir. 
Tablo 12. Gıda Zehirlenmesi Vakalarında Tedavinin Yapıldığı Servislerin Dönemlere Göre Dağılımı

\begin{tabular}{|c|c|c|c|c|c|c|c|c|}
\hline & \multicolumn{6}{|c|}{ Servis } \\
\hline & & & $\begin{array}{c}\text { Acil } \\
\text { Servis } \\
(s=329)\end{array}$ & $\begin{array}{l}\text { Enfeksiyon } \\
\text { Servisi } \\
(\mathrm{s}=1)\end{array}$ & $\begin{array}{c}\text { Çocuk } \\
\text { Hastalıkları } \\
\text { Servisi } \\
(\mathrm{s}=5)\end{array}$ & $\begin{array}{c}\text { İç Hastalıkları } \\
\text { Servisi } \\
(\mathrm{s}=2)\end{array}$ & $\begin{array}{c}\text { Dermatoloji } \\
\text { Servisi } \\
(s=4)\end{array}$ & $\begin{array}{c}\text { Genel } \\
\text { Cerrahi } \\
\text { Servisi } \\
(\mathrm{s}=1)\end{array}$ \\
\hline & 2010 İ1 $6 \wedge$ บ $(s-0)$ & S & 9 & 0 & 0 & 0 & 0 & 0 \\
\hline & LUIU IIK O Ay $(s=y)$ & $\%$ & 100,0 & $0,0 \%$ & $0,0 \%$ & $0,0 \%$ & $0,0 \%$ & $0,0 \%$ \\
\hline & 2010 İkinci 6 Ay & $s$ & 14 & 0 & 0 & 0 & 0 & 1 \\
\hline & $(s=15)$ & $\%$ & 93,3 & 0,0 & 0,0 & 0,0 & 0,0 & 6,7 \\
\hline & 2011 i11 $6 \wedge$ บ $(s-5)$ & s & 4 & 0 & 1 & 0 & 0 & 0 \\
\hline & $\angle U 11$ IIк о Ау (s=) & $\%$ & 80,0 & 0,0 & 20,0 & 0,0 & 0,0 & 0,0 \\
\hline & 2011 İkinci 6 Ay & $\mathrm{s}$ & 6 & 0 & 0 & 0 & 1 & 0 \\
\hline & $(\mathrm{s}=7)$ & $\%$ & 85,7 & 0,0 & 0,0 & 0,0 & 14,3 & 0,0 \\
\hline & 2012 İk 6 Ay & s & 173 & 1 & 0 & 0 & 3 & 0 \\
\hline & $(s=177)$ & $\%$ & 97,7 & 0,6 & 0,0 & 0,0 & 1,7 & 0,0 \\
\hline & 2012 İkinci 6 Ay & s & 3 & 0 & 0 & 0 & 0 & 0 \\
\hline & $(\mathrm{s}=3)$ & $\%$ & 100,0 & 0,0 & 0,0 & 0,0 & 0,0 & 0,0 \\
\hline & & S & 12 & 0 & 1 & 0 & 0 & 0 \\
\hline Dönem & $(s=13)$ & $\%$ & 92,3 & 0,0 & 7,7 & 0,0 & 0,0 & 0,0 \\
\hline & 2013 İkinci 6 Ay & $\mathrm{s}$ & 58 & 0 & 1 & 0 & 0 & 0 \\
\hline & $(\mathrm{s}=59)$ & $\%$ & 98,3 & 0,0 & 1,7 & 0,0 & 0,0 & 0,0 \\
\hline & 2014 ïlk $6 \Delta_{\mathrm{V}}(\mathrm{s}-25)$ & $\mathrm{s}$ & 34 & 0 & 0 & 1 & 0 & 0 \\
\hline & 2014 11к О Ну (3-50) & $\%$ & 97,1 & 0,0 & 0,0 & 2,9 & 0,0 & 0,0 \\
\hline & 2014 İkinci 6 Ay & s & 0 & 0 & 1 & 0 & 0 & 0 \\
\hline & $(\mathrm{s}=1)$ & $\%$ & 0,0 & 0,0 & 100,0 & 0,0 & 0,0 & 0,0 \\
\hline & & s & 9 & 0 & 0 & 0 & 0 & 0 \\
\hline & 2015 IIk 6 Ay $(s=y)$ & $\%$ & 100,0 & 0,0 & 0,0 & 0,0 & 0,0 & 0,0 \\
\hline & 2015 İkinci 6 Ay & s & 6 & 0 & 0 & 1 & 0 & 0 \\
\hline & $(s=7)$ & $\%$ & 85,7 & 0,0 & 0,0 & 14,3 & 0,0 & 0,0 \\
\hline & 2016 i11 $6 \Delta \mathrm{x}(\mathrm{s}-2)$ & s & 1 & 0 & 1 & 0 & 0 & 0 \\
\hline & $\angle U 10$ IIк о Ау $(s=\angle)$ & $\%$ & 50,0 & 0,0 & 50,0 & 0,0 & 0,0 & 0,0 \\
\hline & 2016 İkinci 6 Ay & $\mathrm{s}$ & 0 & 0 & 0 & 0 & 0 & 0 \\
\hline & $(\mathrm{s}=0)$ & $\%$ & 0,0 & 0,0 & 0,0 & 0,0 & 0,0 & 0,0 \\
\hline
\end{tabular}

Gıda zehirlenmesi vakalarının en çok yaşandığı dönem olan 2012 yılının ilk 6 aylık döneminde ve 2011 yılının ikinci 6 aylık döneminde bazı hastaların (s=4) dermatoloji servisinde tedavi gördüğünün tespit edilmesi ilginç bulunmuştur (Tablo 12).

Sağlık İstatistikleri Y1llı̆̆ 2016 [32] verilerine göre; gıda zehirlenmesi vakalarının da içerisinde yer aldığı "Bazı Enfeksiyöz ve Paraziter Hastalıklar (ICD-10 Ana Tanı Kodu: A00-B99)"1n ölüm nedenlerinin dağılımındaki oranı 2014 yılında \%1,78, 2015 y1lında $\% 2,10,2016$ y1lında $\% 2,07$ olduğu, "Yaralanma, Zehirlenme ve Dış Nedenlerin Diğer Bazı Sonuçları (ICD-10 Ana Tanı Kodu: S00-T98)"n ölüm nedenlerinin dağılımındaki oranı 2014 yılında \%5,25, 2015 yılında \%4,77, 2016 yılında \%4,44 olduğu görülmektedir. Cinsiyete göre ölüm nedenlerinin dağılımı tablosunda "Bazı Enfeksiyöz ve Paraziter Hastalıklar (ICD-10 Ana Tanı Kodu: A00-B99)"1n kadınlarda ölüme sebep olma oranının erkeklerden daha yüksek olduğu, ancak, "Yaralanma, Zehirlenme ve Dış Nedenlerin Diğer Bazı Sonuçları (ICD-10 Ana Tanı Kodu: S00-T98)"n kadınlarda ölüme sebep olma oranının erkeklerden daha düşük olduğu kaydedilmiştir. Gıda zehirlenmesi vakalarında teşhislerin mevsimlere göre dağglımı Tablo 13 'te verilmiştir. 
Tablo 13. Gıda Zehirlenmesi Vakalarında Teşhislerin Dönemlere Göre Dağılımı $(p<0,05)$

\begin{tabular}{|c|c|c|c|c|c|c|c|c|c|c|c|c|c|c|}
\hline \multirow{2}{*}{ Mevsimler } & \multicolumn{2}{|c|}{ A05.8 } & \multicolumn{2}{|c|}{ T62.0 } & \multicolumn{2}{|c|}{ T62.9 } & \multicolumn{2}{|c|}{ T62.8 } & \multicolumn{2}{|c|}{ A05.4 } & \multicolumn{2}{|c|}{ A05.9 } & \multicolumn{2}{|c|}{ Toplam } \\
\hline & $\mathrm{s}$ & $\%$ & $\mathrm{~s}$ & $\%$ & $\mathrm{~s}$ & $\%$ & $\mathrm{~s}$ & $\%$ & $\mathrm{~s}$ & $\%$ & $\mathrm{~s}$ & $\%$ & S & $\%$ \\
\hline İlkbahar & 71 & 43,6 & 9 & 60,0 & 1 & 7,7 & 148 & 99,3 & 1 & 100,0 & 0 & 0,0 & 230 & 67,2 \\
\hline Yaz & 8 & 4,9 & 2 & 13,3 & 6 & 46,2 & 0 & 0,0 & 0 & 0,0 & 0 & 0,0 & 16 & 4,7 \\
\hline Sonbahar & 9 & 5,5 & 2 & 13,3 & 5 & 38,4 & 1 & 0,7 & 0 & 0,0 & 1 & 100,0 & 18 & 5,3 \\
\hline $\mathrm{K}_{1 S ̧}$ & 75 & 46,0 & 2 & 13,3 & 1 & 7,7 & 0 & 0,0 & 0 & 0,0 & 0 & 0,0 & 78 & 22,8 \\
\hline Toplam & 163 & 100,0 & 15 & 100,0 & 13 & 100,0 & 149 & 100,0 & 1 & 100,0 & 1 & 100,0 & 342 & 100,0 \\
\hline
\end{tabular}

“A05.8-Gıda zehirlenmeleri, diğer tanımlanmış" teşhisinin konulduğu gida zehirlenmesi olgusunun yaz ve sonbahar mevsimlerinde en az (sırasıyla; \%4,9, \%5,5) yaşandığı, "T62.0-Mantar yemenin toksik etkisi" teşhisinin konulduğu gıda zehirlenmesi olgusunun en çok $(\% 60,0)$ ilkbahar mevsiminde görüldüğü tespit edilmiştir. "T62.9-Gıda olarak yenilen zararlı maddelerin toksik etkisi, tanımlanmamış" teşhisinin konulduğu gıda zehirlenmesi olgusunun en çok $(\% 46,2)$ yaz mevsiminde, "T62.8-Gıda olarak yenilen diğer tanımlanmış zararlı maddelerin toksik etkisi" teşhisinin konulduğu gıda zehirlenmesi olgusunun tamamına yakınının $(\% 99,3)$ ilkbahar mevsiminde yaşandığı saptanmıştır. Sadece birer vakanın görüldüğ̈̈ "A5.04-Gıda kökenli Bacillus cereus zehirlenmesi” teşhisinin konulduğu gida zehirlenmesi olgusunun ilkbahar mevsiminde ve "A5.09-Bakteriyel gida zehirlenmesi, tanımlanmamış" teşhisinin konulduğu gıda zehirlenmesi olgusunun sonbahar mevsiminde görüldüğü belirlenmiştir. Genel bir değerlendirme olarak ise; gıda zehirlenmesi vakalarının en fazla $(\% 67,2)$ yaşandığı mevsimin ilkbahar olduğu anlaşılmıştır (Tablo 13).

Ülkemizde yapılan bazı çalışmalarda da ilkbahar ve yaz aylarında zehirlenme olgularında belirgin artış olduğu saptanmıştır [35, 36].

Türkiye'deki sağlık kurumlarında, gıda zehirlenmesi olgusuyla karşılaşıldığında 2007 yılına kadar kullanılan "Gıda Zehirlenmeleri Formu" uygulamadan kaldırılarak, tüm zehirlenmelerin tek bir çatı altında toplanması amacıyla "Zehirlenme Vaka Bildirim Formu" düzenlenmiş ve gıda zehirlenmesi de dahil tüm zehirlenme vakalarını 24 saat içinde İl/İlçe Sağlık Müdürlüklerine bu formla bildiriminin yapılması istenmiştir. Zehirlenme bildirimde bulunurken, müdahaleyi yapan personel ve müdahalenin gerçekleştiği kuruma ait bilgiler, bildirim formunun düzenlendiği tarih, hastaya ait adres ve kimlik bilgileri, zehirlenme vakasıyla ilgili bilgiler (başvuru tarihi, zehirlenme zamanı ve yeri, zehirlenmede etken olan madde, hastanın şikâyetleri, şikâyetlerin ortaya çıktığı zaman, ölümle sonuçlanmışı durumunda ölüm zamanı) eksiksiz bir şekilde belirtilmelidir [26].

Gıda zehirlenmesi olgularının adli olarak bildiriminin yapılması gerektiği, ilgili tüm sağlık personelinin yasal bir yükümlülüğü olduğu [26] ve Türk Ceza Kanunu'nun (TCK) 280. Maddesine (Görevini yaptı̆̆ sırada bir suçun işlendiği yönünde bir belirti ile karşılaşmasına rağmen, durumu yetkili makamlara bildirmeyen veya bu hususta gecikme gösteren sağllk mesleği mensubu cezalandırılır.) girdiği unutulmamalıdır [37].

Adli bir olguda kayıtların düzgün tutulması ve arşivlenmesi çok önemlidir. Gıda zehirlenmesi olgusuyla karşılaşıldığında, hastaya ait kimlik bilgileri, özgeçmiş, şikayetler, anamnez, fiziki muayeneden elde edilen bulgular, gerçekleştirilen tetkikler ile ilgili sonuçlar ve uygulanmış olan tedavi bilgileri düzenli bir şekilde kayıt altına alınmalı ve gerektiği durumda adli mercilere iletmek üzere arşivlenmelidir [38, 39]. Ayrıca delil niteliği taşıyan, vakaya ait örneklerin usulüne uygun olarak alınması, muhafaza edilmesi ve yetkili kuruluşlara iletilmesi hususunda da tüm sağlık personelinin sorumluluklarını bilmesi ve yapması gerekmektedir [35].

Sebebi ne olursa olsun, tüm zehirlenme olgularında olduğu gibi gıda zehirlenmesi olgusunun da adli olgu kapsamında değerlendirilmesi gerekmektedir [38, 40, 41]. Eksik ya da yanlış bir adli rapor oluşturmak veya hiç düzenlememek, oldukça önemli olan, yasal bir yükümlülüğü yerine getirmemek demektir [40-43].

\section{Sonuç ve Öneriler}

Bitlis Devlet Hastanesi'nde 2010-2016 yılları arasında görülen gıda zehirlenmeleri vakalarının sayısının 342 olduğu tespit edilmiştir. En çok gıda zehirlenmeleri vakası 18-65 yaş arasındaki bireylerde $(\% 59,1)$, erkeklerde $(\% 54,4)$ ve 2012 yılının ilk 6 ayında $(\% 51,8)$ görülmüştür. Vakaların \%47,7'sine A05.8 ICD 
kodlu "gıda zehirlenmeleri, diğer tanımlanmış" teşhisi konulurken; \%43,6'sına T62.8 ICD kodlu "gıda olarak yenilen diğer tanımlanmış zararlı maddelerin toksik etkisi" teşhisi konulmuştur. Hastaların $\% 83,9$ 'u ayakta tedavi edilmiştir. Hastaların yaş aralığı ile poliklinik sonuçları arasındaki farkın anlamlı $(p<0,05)$ olduğu, bağışıklık sistemi yetişkinlere göre daha zayıf olan çocukların (3-11 yaş) daha çok $(\% 67,2)$ yatırılarak tedavi edildiği belirlenmiştir.

Bitlis Devlet Hastanesi'nde görülen gida zehirlenmesi vakalarıyla ilgili istatistiksel verilerin düzenli halleri oldukça zor elde edilmiş, gıda zehirlenmesi vaka bildirimlerinin eksik yapıldığı ve istatistiksel verilerin düzgün olarak kaydedilmediği görülmüştür.

Zehir Danışma Merkezlerinin yapısı ve kullandıkları mevcut bilgi sistemleri güçlendirilmeli, gıda kaynaklı zehirlenmelerde daha etkin olarak faydalanılmalıdır.

Yaygın bir halk sağlığı sorunu olan gıda zehirlenmesi vakalarına etkin bir müdahalenin yapılması için hekimlerin ilgili makamlara gerekli bildirimleri yapması ve ilgili verilerin düzenli bir şekilde kaydedilmesi oldukça önemlidir. Ancak bu sayede gıda zehirlenmesinin asıl sebebinin ve sorumlularının öğrenilmesi mümkün olacaktır.

\section{Kaynaklar}

[1] Baş M. 2004. Gıda hijyeni güvenliği ve HACCP. Sim Matbaacılık, Ankara.

[2] Donald A.C. 1998. HACCP user's manual. Aspen Publishers, Gaithersburg, Maryland.

[3] Bütün C., Beyaztaş F.Y., Engin A., Büyükkayhan D., Can M. 2009. Cumhuriyet Üniversitesi Tıp Fakültesi Adli Tıp Anabilim Dalı'na Başvuran Besin Zehirlenmesi Olgularının Değerlendirilmesi. Van Tıp Dergisi, 16 (1): 19-23.

[4] Merdol T.K., Başoğlu S., Örer N. 1999. Beslenme ve Diyetetik Açıklamalı Sözlük. 2. Baskı, Hatiboğlu Yayınları, Ankara.

[5] FAO/WHO 2002. Pan European Conference on Food Safety and Quality. February, 2002. http://www.fao.org (Erişim Tarihi: 10.12.2016)

[6] Centers for Disease Control and Prevention. 2011. http://www.cdc.gov/Features/dsFoodborneOutbreaks/ (Erişim Tarihi: 08.05.2019).

[7] Food Poisoning Statistics 2013. https://www.edgarsnyder.com/food-poisoning/food-poisoningstatistics.html (Erişim Tarihi: 08.05.2019).

[8] Şimşek F. 2005. Besin Zehirlenmeleri. Toksikoloji Dergisi, 3 (1): 3-9.

[9] Özcan N., İkincioğulları D. 2009. Ulusal Zehir Danışma Merkezi 2008 Yılı Çalışma Raporu Özeti. Türk Hijyen ve Deneysel Biyoloji Dergisi, 66 (3): 29-58.

[10] WHO. 2016. Official World and Health Organization Updates 2016 Package. International Statistical Classification of Diseases and Related Health Problems. 10th Revision, ICD-10 Version:2016. https://www.who.int/classifications/icd/icd10updates/en/ (Erişim Tarihi: 22.01.2019).

[11] Yücel F., Günay Y. 2000. Ölümcül Olmayan Zehirlenme Olgularının Adli Tıp Yönünden Değerlendirilmesi. Adli Tıp Bülteni, 5 (3): 251-253.

[12] Hall A.K. 1994. Changing Epidemiology and Management of Deliberate Self Poisoning in Christcurch. New Zealand Medical Journal, 107 (987): 396-399.

[13] Weir P. 1998. The epidemiology of delibarate self poisoning presenting to Christchurch Hospital Emergency Department. New Zealand Medical Journal, 111 (1063): 127-129.

[14] Urazel B., Çelikal A., Karbeyaz K., Akkaya H. 2014. Gıda Zehirlenmesine Bağlı Rapor Düzenlenen Adli Olguların Değerlendirilmesi. Dicle Medical Journal, 41: 113-117.

[15] Akköse Ş., Fedakar R., Bulut M., Çebiçci H. 2003. Zehirlenme Olgularının Beş Yıllık Analizi. Acil Tip Dergisi, 3 (1): 8-10.

[16] Yeşil O., Akoğlu H., Onur Ö., Güneysel Ö. 2008. Acil Servise Başvuran Zehirlenme Olgularının Geriye Dönük Analizi. Marmara Medical Journal, 21 (1): 26-32.

[17] Özköse Z., Ayoğlu F. 1999. Etiological and Demographical Characteristics of Acute Adult Poisoning in Ankara, Turkey. Human and Experimental Toxicology, 18 (10): 614-618.

[18] Kavalcı C., Durukan P., Çevik Y., Özer M., İkizceli İ. 2006. Zehirlenme Olgularının Analizi: Yeni Bir Hastanenin Bir Yıllık Deneyimi. Türkiye Acil Tıp Dergisi, 6 (4): 163-166.

[19] Yılmaz A., Kukul Güven F., Korkmaz İ., Karabulut S. 2006. Acil Serviste Akut Zehirlenmelerin Retrospektif Analizi. Cerrahpaşa Üniversitesi Tıp Dergisi, 28: 21-26. 
[20] Ok G., Erbüyün K., Mirzai T., Vatansever D., Tok D. 2006. Acil Servise Başvuran Zehirlenme Olgularının Retrospektif Olarak İncelenmesi. Toksikoloji Dergisi, 4 (3-4): 5-9.

[21] Akçay A., Gürses D., Özdemir A., Kılıç İ., Ergin H. 2005. Denizli İlindeki Çocukluk Çağı Zehirlenmeleri. Adnan Menderes Üniversitesi Tıp Fakültesi Dergisi, 6 (1): 15-19.

[22] Tucer D. 2015. Gida Zehirlenmeleri ve Toksik Hepatit. Güncel Gastroenteroloji, 19 (3): 188-196.

[23] Besli G.E., Ergüven M. 2009. Çocuklarda Besin ve Mantar Zehirlenmeleri. Çocuk Enfeksiyonları Dergisi, 3 (3): 126-131.

[24] Bilici S., Uyar F.M., Beyhan Y., Sağlam F. 2008. Besin Zehirlenmeleri, Nedenleri ve Korunma Yolları. T.C. Sağlık Bakanlığı Temel Sağlık Hizmetleri Genel Müdürlüğü Beslenme ve Fiziksel Aktiviteler Daire Başkanlığı, Sağlık Bakanlığı Yayın No: 727, Ankara.

[25] Erkmen O. 2011. Gida Mikrobiyolojisi. Elif Yayınevi, Ankara.

[26] Öz V., Karadayı Ş., Çakan H., Karadayı B., Kaya A. 2014. Acil Tedavi Birimlerinde Gıda Zehirlenmeleri. Marmara Medical Journal, 27: 89-95.

[27] TGK. 2011. Türk Gıda Kodeksi Mikrobiyolojik Kriterler Yönetmeliği. Yayımlandığı Resmi Gazete Tarihi: 29.12.2011, Yayımlandığı Resmi Gazete Sayıs1: 28157.

[28] Ayçiçek H., Aktan H.T. 2003. Gıda Kaynaklı Salgınlarda Soruşturma İlkeleri. Türk Hijyen ve Deneysel Biyoloji Dergisi, 60 (3): 95-99.

[29] Bölükbaş F. 2009. İlaca ve toksik nedenlere bağlı karaciğer hastalıklarına yaklaşım. içinde: Karaciğer Hastalıklarına Klinik Yaklaşım, Değertekin H., Yalçın K. (Ed.)., Pars Yayıncılık, İstanbul, 197-214.

[30] Yardan T., Eden A.O., Baydın A., Aslan B., Vural K. 2008. Mantar Zehirlenmeleri. Journal of Experimental and Clinical Medicine, 25 (2): 75-83.

[31] Oğur S. 2016. Consciousness Level and Knowledge Level of Consumers in Bitlis City about Food Poisoning. International Engineering, Science and Education Conference, 01-03 December, Engineering Proceeding Book, pp: 1152-1168, Diyarbakır, Türkiye.

[32] Sağlık Bakanlığı. 2016. T.C. Sağlık Bakanlığı Sağlık İstatistikleri Yıllığ1 2016. Sağl1k Araştırmaları Genel Müdürlügü̈, Sağlık Bakanlığı Yayın No: 727, Ankara.

[33] İlçe A., Yıldız D., Baysal G., Özdoğan F., Taş F. 2010. Acil Servislerde Çalışan Sağlık Bakım Personelinin Adli Olgularda Delillerin Korunması ve Saklanmasına Yönelik Bilgi ve Uygulamalarının İncelenmesi. Ulusal Travma ve Acil Cerrahi Dergisi, 16 (6): 546-51.

[34] Karadayı B., Kolusayın M.Ö., Kaya A., Karadayı Ș. 2013. Acil Tedavi Birimlerinde Adli Olgudan Biyolojik Materyal Alınması ve Gönderilmesi. Marmara Medical Journal, 26 (3): 111-117.

[35] Bostancı İ., Küpelioğlu M., Bedir E., Cinbiş M., Akşit M.A. 1999. Çocuk Zehirlenme Olgularının Retrospektif Değerlendirilmesi. Türkiye Klinikleri Pediatri Dergisi, 8: 143-146.

[36] Aji D.Y., Keskin S., İlter Ö. 1998. İ. Ü. Cerrahpaşa Tıp Fakültesi Çocuk Sağlığı ve Hastalıkları Anabilim Dalı Acil Biriminde İzlenen Zehirlenmelerin Değerlendirilmesi. Türk Pediatri Arşivi, 33: $148-153$.

[37] Resmi Gazete 2014. Türk Ceza Kanunu. http://www.resmigazete.gov.tr/eskiler/2004/10/20041012.htm (Erişim Tarihi: 16.01.2017)

[38] Gürpınar T., Aşırdizer M. 2006. Zehirlenmelerde Hekim Sorumluluğu. Türkiye Klinikleri Journal of Surgical Medical Sciences, 2 (50): 56-62.

[39] Yavuz S. 2006. Tıbbi Kayıtların Düzenlenmesi ve Saklanmasında Görülen Eksiklikler ve Hukuki Sonuçları. Türkiye Klinikleri Journal of Surgical Medical Sciences 2 (50): 20-27.

[40] Karbeyaz K., Gündüz T., Akkaya H., Urazel B., Kökçüoğlu M.A. 2012. Adli Raporlara Dikkat; Eskişehir Deneyimi. Sürekli Tıp Eğitimi Dergisi, 21 (5): 292-296.

[41] Tuğcu H., Yorulmaz C., Ceylan S., Baykal B., Celasun B., Koç S. 2003. Acil Servis Hizmetine Katılan Hekimlerin, Acil Olgularda Hekim Sorumluluğu ve Adli Tıp Sorunları Konusundaki Bilgi ve Düşünceleri. Gülhane Tıp Dergisi, 45: 175-179.

[42] Tüzün B., Elmas İ., Akkay E. 1998. Adli Rapor Düzenleme Zorunluluğuna Hekimlerin Yaklaşımı. Adli Tıp Bülteni, 3 (1): 27- 31.

[43] Bengidal M.S., Keskinkılıç B., Kuvan L., Odabaşı O., Bengidal S. 2001. Acil Servislerde Hekimin Adli Sorumluluğu. Step, 10 (8): 301-305. 